\title{
Palaeomagnetic dating of two recent lava flows from Ceboruco volcano, western Mexico
}

\author{
Harald Böhnel, ${ }^{1}$ Francisco Javier Pavón-Carrasco, ${ }^{1, *}$ Katrin Sieron ${ }^{2}$ \\ and Ahmed Nasser Mahgoub ${ }^{1}$ \\ ${ }^{1}$ Centro de Geociencias, Universidad Nacional Autónoma de México (UNAM), Blvd. Juriquilla No. 3001, Querétaro 76230, Mexico. \\ E-mail:hboehnel@geociencias.unam.mx \\ ${ }^{2}$ Centro de Ciencias de la Tierra, Universidad Veracruzana, Francisco J. Moreno \# 207, Col. Emiliano Zapata, C.P. 91090 Xalapa, Mexico
}

Accepted 2016 August 12. Received 2016 August 11; in original form 2015 December 7

\begin{abstract}
SUMMAR Y
Two lava flows from the Ceboruco volcano in west-central Mexico were sampled for palaeomagnetic dating. The younger one was emitted in 1870 and used to validate the method, while the older one known as Ceboruco flow is of unknown age but probably younger than $\sim 1005$ $\mathrm{AD}$ and older than $1528 \mathrm{AD}$. Each flow was sampled in at least four sites, in order to unravel between site variations. For the 1870 flow, between site differences were notable and additionally post-cooling block movements were important; therefore, two sites had to be rejected. Three sites from the vent area and one at the tip of the 1870 flow provided well-constrained directions. This is also true for Ceboruco lava flow, and overall mean directions and palaeointensities were then used for palaeomagnetic dating applying the Matlab tool archaeo_dating and the global palaeosecular variation model SHA.DIF.14k. For the 1870 lava flow, the dating resulted in an age ranging between 1755 and $1871 \mathrm{AD}$ (95 per cent probability level), which includes the real emplacement age. In addition, the Ceboruco lava flow was dated between 1000 and $1134 \mathrm{AD}$, which is close to the large plinian Jala eruption producing the crater of Ceboruco volcano around $1005 \mathrm{AD}$. This age is older than previously assumed and suggests an emplacement only shortly after the Jala eruption. As this lava flow is considered to be the youngest one of seven post-Jala lava flows, the age also defines a period of inactivity of Ceboruco volcano of about $730-860$ yr before the historic 1870 eruption. Future volcanic hazard analysis will have to take into account this result. Our work also shows that multiple sampling of single lava flows is important to obtain a reliable mean direction. Sampling sites have to be carefully selected so that they represent un-tilted parts of the flows. We interpret this to be the case for the Ceboruco lava flow, while three of the six sites of the 1870 lava flow may have been partly or completely affected by movements after thermoremanent magnetization acquisition. Unfortunately, no better sites were found for this flow.
\end{abstract}

Key words: Palaeointensity; Palaeomagnetic secular variation; Palaeomagnetism applied to geologic processes; Volcanic hazards and risks.

\section{INTRODUCTION}

Palaeomagnetic dating is based on the comparison of the geomagnetic field recorded in suitable material of unknown age with a set of reference data of known age, established for the same geographical region, which are used to constrain the classical palaeosecular variation (PSV) master curves. During the last few decades, this method has been used increasingly for palaeomagnetic dating, using the

\footnotetext{
* Now at: Grupo de Paleomagnetismo, Universidad Complutense de Madrid, Avda. Complutense, s/n. E-28040 Madrid, Spain.
}

thermoremanent magnetization (TRM) produced in pottery or kilns during the last firing. The availability of detailed SV master curves for the last millennia (e.g. Gallet et al. 2002; Gómez-Paccard et al. 2006; Kovacheva et al. 2009; Hagstrum \& Blinman 2010) has also allowed applying the same methodology for the dating of young lava flows that have been emplaced during the last few thousand years (e.g. Tanguy et al. 2003; Arrighi et al. 2006; Speranza et al. 2006, 2008; Hagstrum \& Blinman 2010; Roperch et al. 2015). However, the palaeomagnetic dating presents some limitations (e.g. McIntosh \& Catanzariti 2006; Pavón-Carrasco et al. 2011). The method strongly depends on the PSV master curve used for dating and how this curve has been constrained by well-dated 


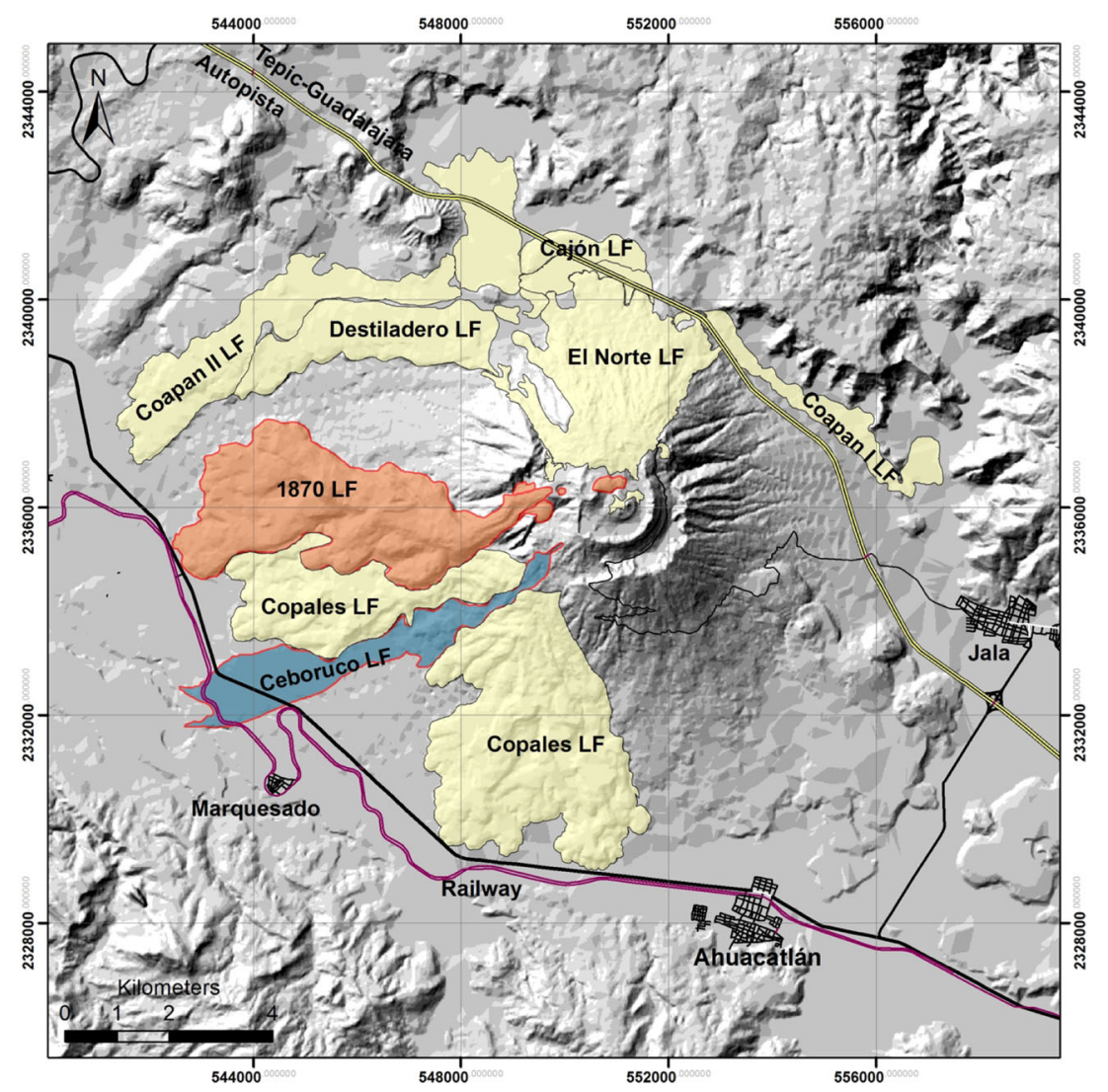

Figure 1. Digital elevation model of Ceboruco volcano, showing the pre-plinian Destiladero lava flow and the seven post-plinian lava flows, including the two dated lava flows (Ceboruco and 1870). Railway (pink), highway (yellow) from Guadalajara to Tepic to the N of Ceboruco and main toll-free roads (black) area also shown, as well as the most important villages.

palaeomagnetic data. In addition, the behaviour of the Earth's magnetic field itself, with cyclical values of declinations and inclinations, can provide several ages for the same volcanic event. These limitations clearly affect our results since, currently, no wellconstraint PSV master curve for Mexico is available covering the last millennia. To solve this problem, we need to use a synthetic PSV curve calculated from a global palaeomagnetic model that has been developed by using all the palaeomagnetic data available all around the world.

Such dating is of interest for evaluating the volcanic hazard in active volcanic regions, which often are densely populated (e.g. Italy, Japan, Mexico, Central and South America, Hawaii, Azores and New Zealand). To be able to determine the actual volcanic hazard for a certain region, the eruptive history of the volcanoes must be completely known in order to permit calculating exact recurrence intervals of eruptions and hence the probability of occurrence. Dating lava flows by traditional methods often fails: for applying the ${ }^{14} \mathrm{C}$ dating method, charred organic material is required that unambiguously was produced by the emplacement of the lava flow. Searching for such carbon source has often been unsuccessful or leads to multiple ages that are younger or older than the lava emplacement and thus may be misinterpreted (e.g. Siebe et al. 2004).

Here, we report results from two lava flows from the Ceboruco volcano, western Mexico. One flow was emplaced shortly after the historic eruption in 1870, and the so-called Ceboruco flow is probably younger than $1005 \mathrm{AD}$ and thus also of historic age, but older than the first arrival of Spanish conquerors at the region in 1528 . No clear evidence was found about any pre-
Spanish historic records (Sieron \& Siebe 2008). In this work, we use the 1870 lava to see how works the palaeomagnetic dating method in this region and then apply it to the Ceboruco flow with unknown age.

\section{GEOLOGICAL HISTORY OF CEBORUCO VOLCANO}

Ceboruco volcano is active since late Quaternary and has an andesitic cone built up mainly by effusive activity which is truncated by two summit craters. This first cone-constructing phase (Nelson 1980) ended approximately $45 \pm 8 \mathrm{ka}$ ago (Frey et al. 2004), as the age of a lava dyke inside the outer crater walls indicates, representing one of the youngest structures of the andesitic cone. After a longer phase of quiescence, Ceboruco volcano erupted violently (VEI 6) at $1005 \pm 15 \mathrm{AD}$ (details of this dating are found in Sieron \& Siebe 2008; all ages denoted as AD are calibrated and calculated from ${ }^{14} \mathrm{C}$ ages), emitting $3-4 \mathrm{~km}^{3}$ of magma (Gardner \& Tait 2000) during the so-called plinian Jala eruption (Nelson 1980). This eruption included major changes in eruptive style and magma composition, compared to the first coneconstruction phase. During this catastrophic eruption, pumice fallout was deposited mainly to the NE and associated pyroclastic flow and surge deposits were predominantly emplaced to the SW. The plinian Jala eruption produced the outer summit crater, while the inner crater was formed by the drainage of the voluminous Copales lava flow (Fig. 1) and subsequent collapse of the Dos Equis lava 

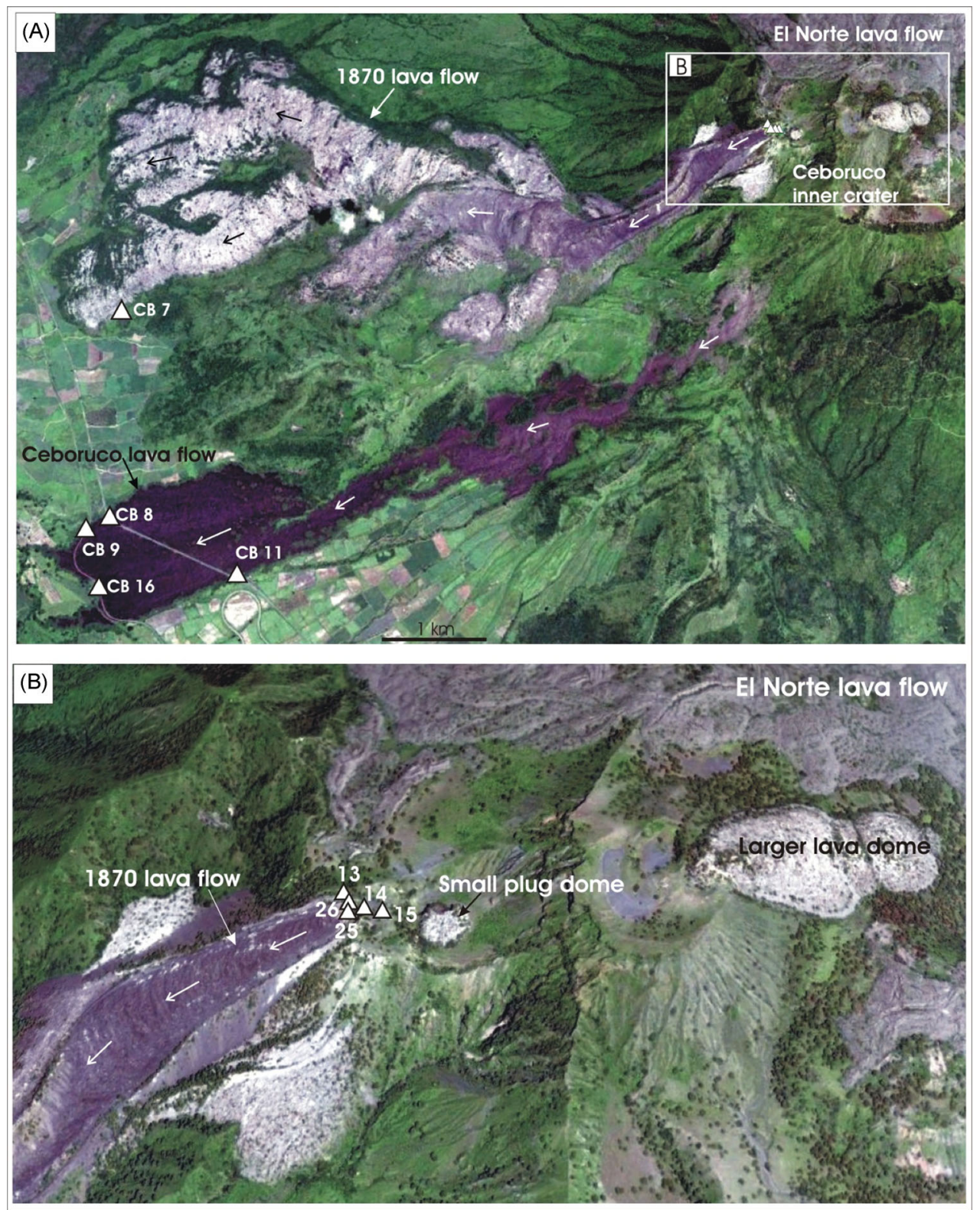

Figure 2. (A) Overview Google Earth image of the 1870 and Ceboruco lava flows, with sampling sites marked as white triangles. (B) Closeup of the Ceboruco crater with the 1870-75 eruption products and sampling sites. Flow directions are indicated by white and black arrows.

dome which grew inside the outer crater probably shortly after the plinian Jala eruption (Nelson 1980). The widespread Jala pumice can be used as a marker horizon, assigning pre-Jala and post-Jala relative ages to the several morphologically young looking lava flows covering the main cone's flanks.

Consequently, the rhyodacitic Destiladero lava flow (W-flank) was emplaced before the plinian Jala eruption, while at least seven other lava flows (from old to young: Copales, Cajón, Coapan I, Coapan II, El Norte, Ceboruco and the historical 1870 lava flow) descended the flanks after the Plinian eruption (Fig. 1). These very recent eruptions with a total volume of about $4 \mathrm{~km}^{3}$, occurring after $1005 \mathrm{AD}$, are difficult to date by the radiocarbon method, mainly because of the short between eruption intervals not permitting any soil formation.

Except for the historical 1870 lava flow, none of the others eruptions has been described in historical documents, although legends are referring to past activity of Ceboruco volcano but without any time reference. This means that all post-plinian lava flows had already been emplaced by the arrival of the Spanish conquerors in 1528.

Apart of the lava flow emission, several smaller lava domes and pyroclastic cones were emplaced inside the inner summit crater (Fig. 2), which might have been source of historic references to volcanic activity without lava flow emission (see Sieron \& Siebe 2008 and Sieron 2009, for more detail).

\subsection{CEBORUCO lava flow}

Stratigraphically, El Norte lava flow is the youngest lava flow on the northern side and Ceboruco lava flow on the southern flank (Fig. 1), not taking into account the historical 1870 eruption. Only legends exist about eruptions before 1528 , which were passed on orally from one generation to the next and were eventually written down 
by Spanish chroniclers, but therefore caressing specific eruption dates. One of these, repeatedly quoted by different authors (e.g. Tello 1968; Mota y Padilla 1973; de Ciudad Real 1976) tells a story about a village at the volcano flank which was buried by a lava flow because the inhabitants had sinned.

While Nelson (1980) described the Ceboruco flow as a blocky lava flow, we characterize it rather as an Aa-type lava flow, because of the surface morphology, thickness and the presence of basal and top breccias and a massive, dense, central part.

For its characteristics, including almost no vegetation cover, black colour and the rugged surface of the lava blocks, the Ceboruco lava flow often has been confounded with the historical 1870 lava flow (e.g. Thorpe \& Francis 1975; Michalk et al. 2008), which indeed is characterized by more vegetation. Ceboruco lava flow is andesitic and has a porphyritic texture, showing larger plagioclase phenocrystals and abundant vesicles in the upper parts of the flow.

\section{$2.21870-75$ eruption}

The only historical eruption documented in detail started the 1870 February 23 and lasted until 1875, although the associated dacitic lava flow stopped moving laterally in 1872 already (García 1875; Iglesias et al. 1877). The eruption was preceded by precursors like noise, seismic activity and vapour emission and was characterized by intense ash fallout, lava extrusion and probably small pyroclastic flows. The products involve the lava flow and two smaller domes, one sealing the 1870 vent (recognized by 19 th century observers) and the other larger one to the $\mathrm{E}$ on the flank of the pyroclastic cone (Fig. 2).

The 1870-72 lava is light to medium grey, glassy to vesicular, also showing a porphyritic texture with plagioclase phenocrysts, typical of Ceboruco's post-plinian andesites and dacites. Due to the great thickness and the presence of dense blocks on the surface with few vesicles, we describe the 1870 flow as an authentic block lava flow. Emplacement probably took part by flow inflation, as already proposed by Iglesias et al. (1877).

\section{FIELD WORK}

For palaeomagnetic studies, we collected $25 \mathrm{~mm}$ cores in the field with a portable gasoline powered drill. Cores were between about 5 and $12 \mathrm{~cm}$ long and oriented in situ with a new device equipped with a digital inclinometer $\left(0.1^{\circ}\right.$ resolution and 0.2 in situ precision $)$, a magnetic compass ( 0.5 in situ divisions, readable through an ocular) and a sun compass with 0.5 in situ divisions (for more details on the orienting device see Supporting Information).

To find out about the internal consistency of the palaeomagnetic data within a particular flow, multiple sites were sampled. It has been previously reported (e.g. Hagstrum \& Champion 1994; Speranza et al. 2006) that mean directions may be significantly different along the same lava flow, which can pose a problem for the application in palaeomagnetic dating. Similarly, Lanza et al. (2005) found that individual and well-defined site-mean directions may be significantly different from observatory directions. Finding suitable sites sometimes was a difficult task at Ceboruco volcano, as the two lava flows are very thick and/or characterized blocky surfaces which probably still moved long after cooling below the remanence acquisition temperature, possibly related to inflation-type emplacement mechanism, especially in the case of the very thick dacititic lava flows (1870 and Copales flows). In the case of the Ceboruco flow, four sites produced by road and rail-road cuts (Fig. 2) were selected, where the internal structure of the lava was visible over dozens of metres and seen unaffected by any important fractures pointing to post-cooling movements of the rock. The 1870 flow is not cut by any kind of road, and thus only natural outcrops could be sampled. Close to the end of the lava flow tongue very large blocks were visible at an intermediate elevation of the flow, where part of the rock had been removed and potentially the massive interior of the flow was accessible. As dictated by the steep topography and dense vegetation, three patches were sampled over a total distance of about $50 \mathrm{~m}$. Two patches included exposures of $3 \mathrm{~m}$ or less, and the continuity of rock could not be established between them. The third part was much larger and here the undisrupted lava rock could be observed for more than $30 \mathrm{~m}$ Additionally, we sampled other sites close to the vent area (Fig. 2): CB13 was taken from a levee of the 1870 flow at the top of the outer crater rim. CB15 is the remnant of a plug or a dyke of the 1870 vent, and four drill cores were also taken from the nearby dome or main plug. CB14 is located along the massive inner walls of the vent, and CB25 and CB26 on the massive outside wall of the vent.

\section{LABORATORY PROCEDURES}

Drill cores were cut in the laboratory into $22 \mathrm{~mm}$ long specimens and their magnetic susceptibility measured with an AGICO KLY-3 instrument. Natural remanent magnetization (NRM) vectors were determined with an AGICO JR-5 spinner magnetometer, and stepwise alternating field (AF) demagnetization was carried out with the AGICO LDA-3 equipment, in maximum field amplitudes of $100 \mathrm{mT}$. Demagnetization data were analysed by the program PMGSC 4.2 (Randy Enkin, Geological Survey of Canada). For statistical analysis and graphical representation of data, the program PMag Tool 4.2 b by Mark W. Hounslow was used. Sitemean directions were calculated from averaged directions on core level, when several specimens were measured. Overall mean directions for the two lava flows were determined based on sitemean directions, as well as averaging all cores from the selected sites.

Rock magnetic measurements include the determination of magnetic hysteresis curves with a Princeton Measurement Corp. model MicroMag 2900 instrument, and thermomagnetic analysis of highfield-induced magnetization with a horizontal Curie balance built in the laboratory. For thermal demagnetization and palaeointensity (PI) experiments, an ASC Scientific TD48 furnace was used. PI were determined by the Thellier (1959) method with the modification proposed by Coe (1967) (TTC method). pTRM checks (Coe 1967), pTRM-tail check (Riisager \& Riisager 2001) and additivity checks (Krása et al. 2003) were performed to obtain criteria regarding the reliability of the results. Data were analysed with the Thellier Tool software (Leonhardt et al. 2004). Additionally, PI were determined by the multispecimen method of Dekkers \& Böhnel (2006) (MSP-DB), and with the modified protocol proposed by Fabian \& Leonhardt (2010) (MSP-DSC) to include a domain state correction and alteration test. In the analysis of these data, we used a domain state proxy ( $\alpha$-parameter) of 0.5 as suggested by Fabian $\&$ Leonhardt (2010). The MSP-DSC data were analysed using MSPTool (Monster et al. 2015). Three reliability criteria have been considered in this study. Thermal-induced alteration $\left|\varepsilon_{\text {alt }}\right|$ (Fabian \& Leonhardt 2010; Monster et al. 2015) during the experiment must be the lowest possible (the alteration criterion): specimens with $\left|\varepsilon_{\text {alt }}\right|>4$ per cent will be rejected from the analyses. The maximum allowed angle between the isolated NRM and pTRM was set to $10^{\circ}$, defining the directional criterion (Monster et al. 2015). 


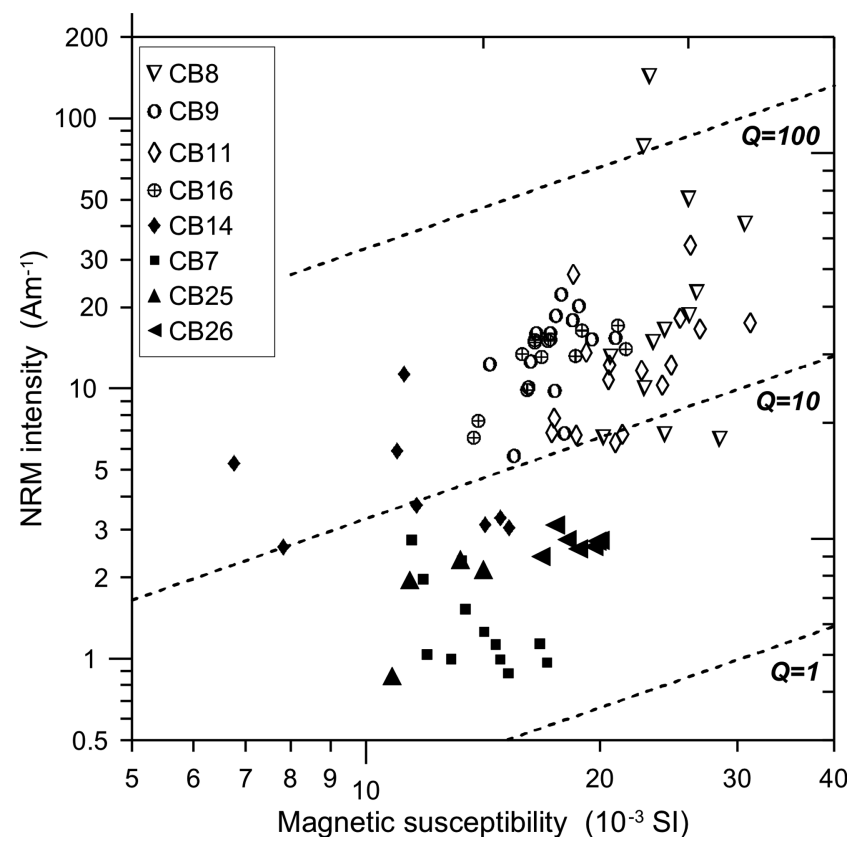

Figure 3. Variation of NRM intensity and magnetic susceptibility for Ceboruco (white symbols) and 1870 (black symbols) lava flows. Interrupted lines define constant values of Königsberger's factor $Q$.

Furthermore, the third, intersection criterion $(\Delta b)$ (Monster et al. $2015)$ tests whether the linear fit regression line intersects the $y$-axis at the theoretically predicted value of -1 . A threshold value of $(\Delta b)$ is \pm 0.1 : the interpreted MSP-DSC linear best fit should intersect the $y$-axis between -0.9 and -1.1 .

\section{RESULTS}

The magnetic declination in our sampling area was found to be quite variable, showing site average values between about $4^{\circ} \mathrm{W}$ and $13^{\circ} \mathrm{E}$, over distances of a few hundred metres to several kilometres.

\subsection{Magnetic properties}

Fig. 4 shows the variation of the NRM intensity and magnetic susceptibility for the eight studied sites, together with lines of constant Königsberger's factor $Q$, which is the ratio between remanent and induced magnetization, $Q=\mathrm{NRM} / \kappa \cdot H$, where $\kappa$ is the initial magnetic susceptibility and $H=33 \mathrm{Am}^{-1}$ the magnetic field intensity. The Ceboruco flow has a geometrical average NRM intensity of $12.04 \mathrm{Am}^{-1}$, calculated without the five highest values of NRM $>33 \mathrm{Am}^{-1}$, which are suspect of being produced by nearby lightning strikes. Susceptibility values are on geometrical average 19.5 $\times 10^{-3}$ (SI). Both properties together define $Q$ values between 10 and 100 . Average values for the 1870 lava flows are clearly smaller, $\mathrm{NRM}=2.09 \mathrm{Am}^{-1}$ (excluding three values of $\mathrm{NRM}>5 \mathrm{Am}^{-1}$ ), and $\kappa=14.26 \times 10^{-3}(\mathrm{SI})$. Most 1870 specimens have $Q$ values between about 2 and 10, and are clearly separated in the NRM versus susceptibility diagram from the Ceboruco flow specimens (Fig. 3).

Magnetic hysteresis curves of rock chips are similar for both lava flows, as visible in Fig. 4. All hysteresis curves close in fields $<250$ $\mathrm{mT}$, indicating the presence of low-coercivity minerals like magnetite or titanomagnetite. Values of coercive force are on average $8.3 \pm 1.9 \mathrm{mT}$ (Ceboruco flow) and $8.2 \pm 2.3 \mathrm{mT}$ (1870 flow) and thus indistinguishable. Saturation magnetization $M_{s}$ is higher for
Ceboruco flow $\left(7.7 \pm 1.9 \times 10^{-4} \mathrm{Am}^{2} \mathrm{~kg}^{-1}\right)$ than for the 1870 flow $\left(6.0 \pm 2.3 \times 10^{-4} \mathrm{Am}^{2} \mathrm{~kg}^{-1}\right)$. The difference is larger for the remanent saturation magnetization $M_{\mathrm{rs}}, 1.4 \pm 0.3 \times 10^{-4}$ and $0.82 \pm 0.23 \times 10^{-4} \mathrm{Am}^{2} \mathrm{~kg}^{-1}$, respectively. Magnetization ratios $M_{\mathrm{rs}} / M_{s}$ and coercivity ratios $H_{\mathrm{cr}} / H_{c}$ are plotted in a Day et al. (1977) plot (Fig. 5) and indicate slightly smaller magnetic grain sizes for Ceboruco flow than for 1870 flow. In the Day plot, the data points are located slightly to the right of the theoretical SD-MD mixing lines given by Dunlop (2002).

Median destructive fields (MDF) are 20-40 mT for Ceboruco flow and 10-20 mT for 1870 flow, confirming the presence of more multidomain-like particles in the historic lava flow.

Results of thermomagnetic analysis are shown in Fig. 5, often indicating the presence of two minerals with Curie temperatures $T_{c}$ around $250-300{ }^{\circ} \mathrm{C}$ and $500-550{ }^{\circ} \mathrm{C}$ (Fig. 5). These Curie temperatures suggest the simultaneous occurrence of Ti-rich and Ti-poor titanomagnetite minerals. The relative concentration of these minerals is variable as indicated by the drop of the magnetization around $300{ }^{\circ} \mathrm{C}$, and only in specimen CB14-1 (Fig. 5a) from the 1870 lava flow the low-Ti titanomagnetite seems to be largely dominating. Cooling curves are very similar to the heating curves, often with a slightly smaller magnetization and thus indicating partial oxidation of the magnetic minerals. The Curie curves from both lava flows show similar variability of low-Ti and high-Ti titanomagnetites.

\subsection{Characteristic remanence and flow-mean directions}

One specimen of every drill core was demagnetized in up to 10 steps, using AF amplitudes of up to $100 \mathrm{mT}$, and all demagnetization curves were analysed with the principal component method (Kirschvink 1980; program PMGSC 4.2). Mostly, between five and nine demagnetization steps were used to obtain the characteristic remanence direction (ChRM), with a maximum angular deviation (MAD) less than $2^{\circ}$ and often $<1^{\circ}$. Most of the specimens showed only minor secondary magnetization components of probably viscous origin, which were removed in AF amplitudes of $20 \mathrm{mT}$ or less (Figs 6a and b). Specimens with stronger secondary components (Figs $6 \mathrm{c}$ and d) were probably affected by lightning strikes, and AF amplitudes to remove the overprint were higher, up to 50 mT. Nevertheless, in all such cases, we still obtained a stable end direction, which is similar to that of other specimens from the same site unaffected by such overprints.

Site-mean directions were calculated assuming a Fisher distribution (using PMag Tools Version 4.2), and after testing for outliers at the 95 per cent confidence level. Tables 1 and 2 list these data for the 1870 lava and Ceboruco flow sites, respectively. Also indicated are overall flow-mean directions calculated from all ChRM directions, as well as calculated from the site-mean directions. We note here that of course the confidence limits $\alpha_{95}$ are smaller for the first case, due to the much larger number of individual directions.

Sites CB13 (dyke or plug remnant) and CB15 (levee) and specimens from the central dome of the 1870 lava flow showed highly dispersed ChRM directions and no site mean was calculated. Individual demagnetization diagrams are of high quality, similar to other sites and best fits have small MAD values. Therefore, the dispersion probably reflects post-cooling movement of the rocks, although this was not detected in the field. ChRM directions for site CB7 of the 1870 lava flow are less but also dispersed. Here, the specimens recovered from the two small parts produced most of the dispersion, while specimens from the extended and undisrupted part showed coherent directions which resemble those of the other 

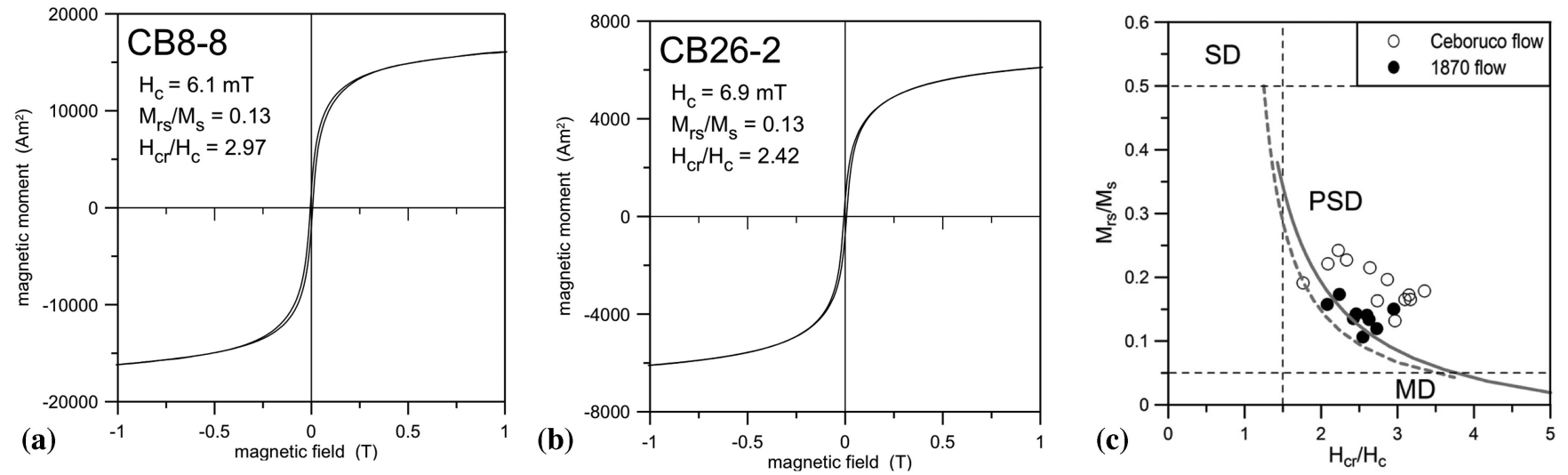

Figure 4. Examples of magnetic hysteresis curves for selected samples from (a) Ceboruco lava flow, (b) 1870 lava flow and Day plot. Interrupted straight lines distinguish magnetic grain sizes: SD: single-domain range, PSD: pseudo-single-domain range, MD: multidomain range. Continuous and interrupted curves represent theoretical mixing curves for SD and MD mixtures according to Dunlop (2002).
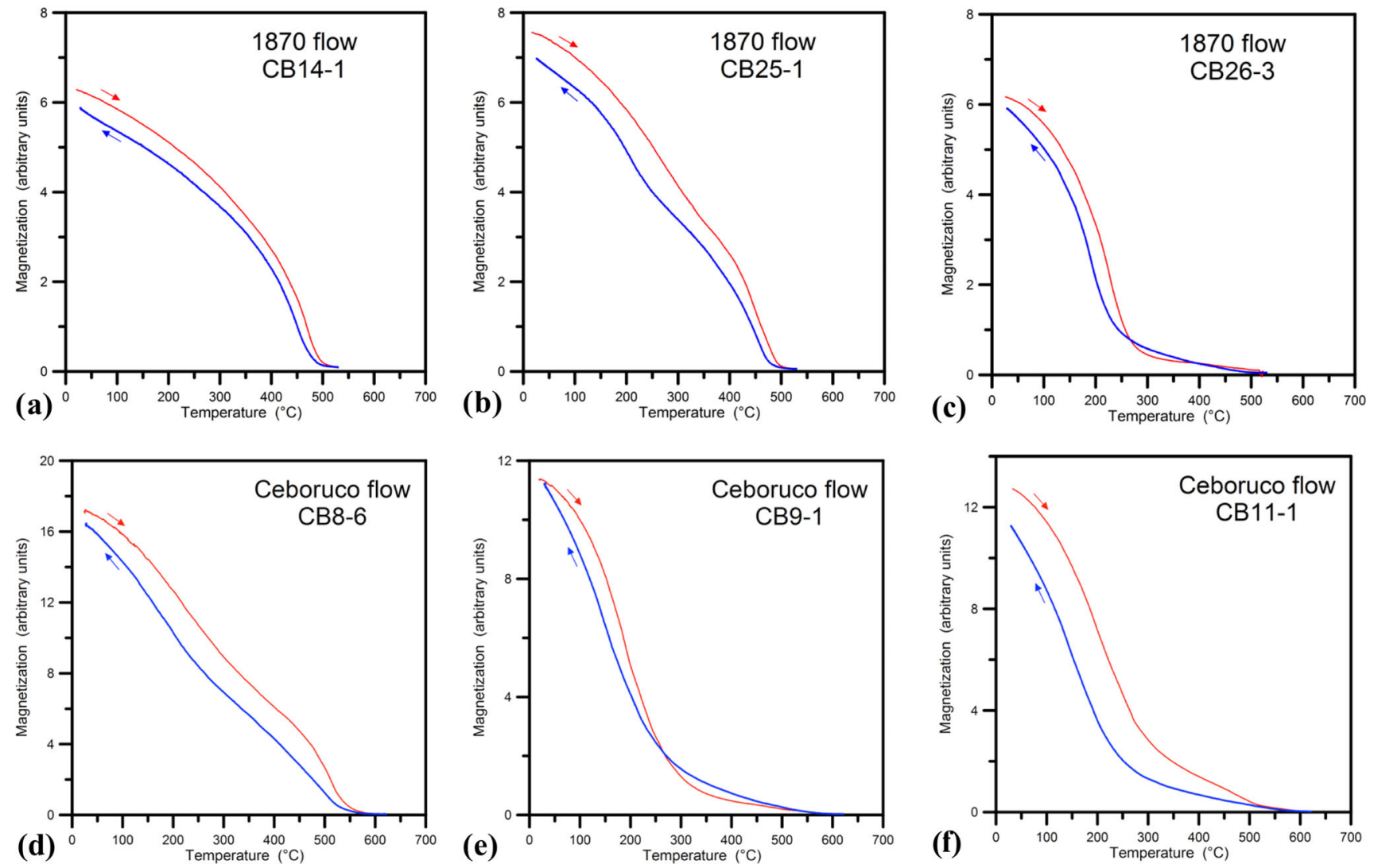

Figure 5. Variation of high-field-induced magnetization with temperature for samples from (a)-(c) 1870 lava flow and (d)-(f) Ceboruco lava flow. Heating and cooling curves are indicated by arrows and red and blue colours, respectively.

sites. Only these specimens were used to calculate the mean direction indicated in Table 1. Sites CB14, 25 and 26, all from locations close to the 1870 vent, have similar ChRM directions and define site-mean directions with a lower dispersion (Table 1 and Fig. 7). When calculating an overall mean based on site-mean directions, a relatively large uncertainty of $\alpha_{95}=8.6^{\circ}$ is obtained, due to the small number $n=4$ of sites. On the other hand, the overall mean direction based on the total number $n=25$ of ChRM data is very well defined: $D=7.5^{\circ} \mathrm{E}, I=42.3^{\circ}, \alpha_{95}=3.1^{\circ}$, although it is not significantly different from the mean direction mentioned before. We would like to note that the obtained declination is indistinguish- able within the uncertainty from the magnetic declination of $9.6^{\circ}$ reported by Iglesias et al. (1877) for the year 1875. This historical declination was marked in a geological map of that work, although the location where this value was determined is unknown (see fig. 5 in Sieron \& Siebe 2008).

ChRM directions were determined for all four sites from Ceboruco flow (Table 2 and Fig. 8). Again, the confidence circle for the overall mean direction of the Ceboruco flow is larger when calculated from four site means $\left(\alpha_{95}=5.8^{\circ}\right)$, compared to that based on $n=50 \mathrm{ChRM}$ data, $D=347.1^{\circ} \mathrm{E}, I=36.2^{\circ}$ and $\alpha_{95}=2.4^{\circ}$. 

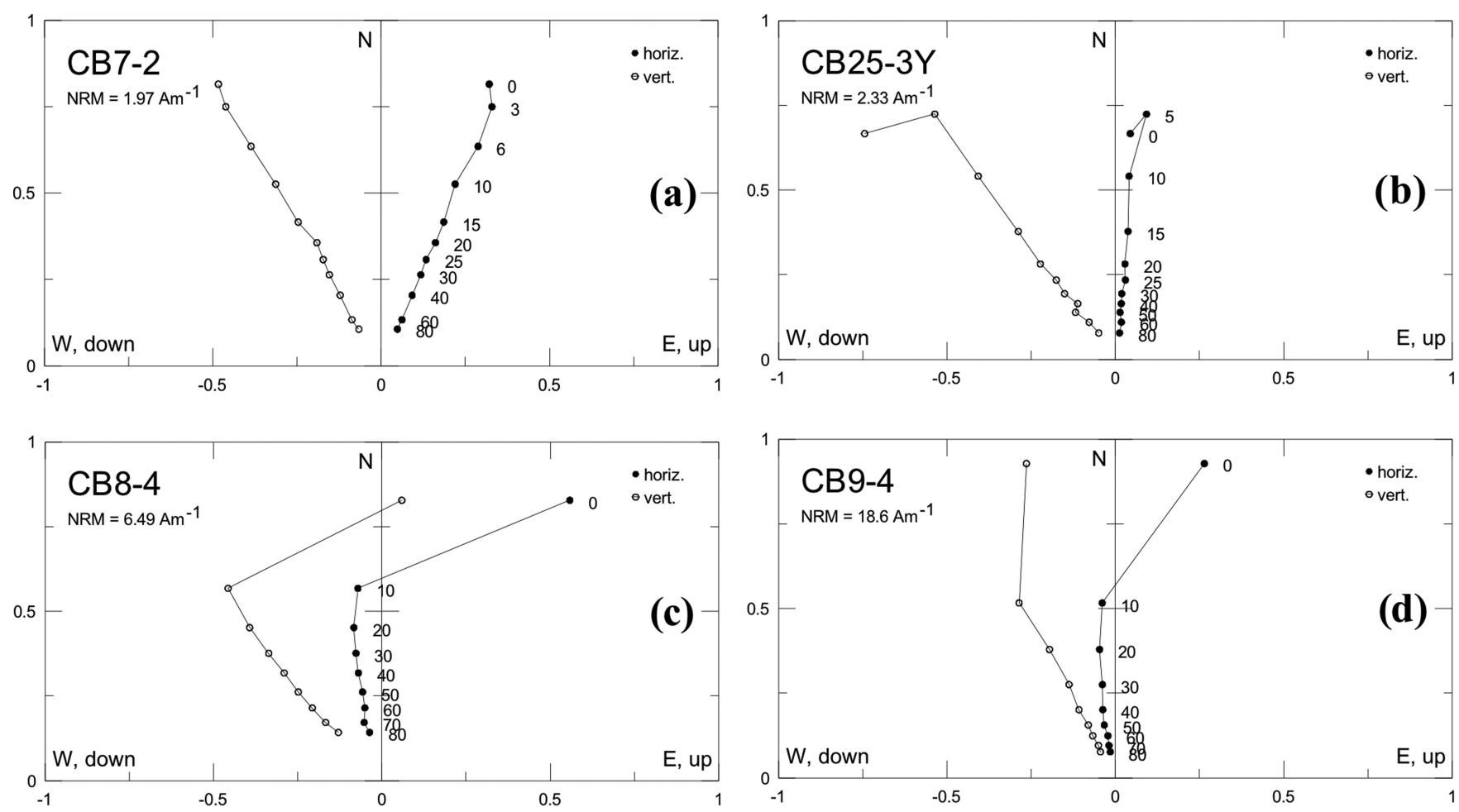

Figure 6. Orthogonal vector plots of AF demagnetized samples from (a) and (b) 1870 lava flow and (c) and (d) Ceboruco lava flow. Labels along curves denote the maximum AF amplitude applied during the demagnetization step.

Table 1. Site-mean directions for four sites of the 1870 lava flow, with sampling coordinates; $N$, number of recovered drill cores; $N^{\prime}$, number of samples used for calculation of site-mean direction; $R$, unit vector sum; $k$, precision parameter; $\alpha_{95}, 95$ per cent confidence level; Dec, declination; Inc, inclination.

\begin{tabular}{lccccccccc}
\hline Site & Latitude & Longitude & $N$ & $N^{\prime}$ & $R$ & $k$ & $\alpha_{95}$ & Dec & Inc \\
\hline CB7 & $21^{\circ} 6.873^{\prime}$ & $104^{\circ} 34.944^{\prime}$ & 15 & 6 & 5.94145 & 85.4 & 7.3 & 358.0 & 47.2 \\
CB14 & $21^{\circ} 7.643^{\prime}$ & $104^{\circ} 31.254^{\prime}$ & 8 & 8 & 7.99176 & 849.7 & 1.9 & 10.1 & 45.9 \\
CB25 & $21^{\circ} 7.627^{\prime}$ & $104^{\circ} 31.278^{\prime}$ & 4 & 4 & 3.99283 & 418.5 & 4.5 & 13.6 & 36.2 \\
CB26 & $21^{\circ} 7.629^{\prime}$ & $104^{\circ} 31.278^{\prime}$ & 7 & 7 & 6.95633 & 137.4 & 5.2 & 8.1 & 37.1 \\
Mean & Core level & 34 & 25 & 24.73413 & 90.3 & 3.1 & 7.5 & 42.3 \\
Mean & \multicolumn{2}{c}{ Site level } & 4 & 4 & 3.97394 & 115.1 & 8.6 & 7.8 & 41.7 \\
\hline
\end{tabular}

Table 2. Site-mean directions for four sites of the Ceboruco lava flow, for details see Table 2.

\begin{tabular}{lccccccccc}
\hline Site & Latitude & Longitude & $N$ & $N^{\prime}$ & $R$ & $k$ & $\alpha_{95}$ & Dec & Inc \\
\hline CB8 & $21^{\circ} 5.739^{\prime}$ & $104^{\circ} 34.897^{\prime}$ & 12 & 12 & 11.84274 & 69.95 & 5.2 & 346.5 & 40.8 \\
CB9 & $21^{\circ} 5.767^{\prime}$ & $104^{\circ} 35.100^{\prime}$ & 13 & 11 & 10.86459 & 73.85 & 4.9 & 346.5 & 36.7 \\
CB11 & $21^{\circ} 5.437^{\prime}$ & $104^{\circ} 34.214^{\prime}$ & 14 & 14 & 13.90264 & 133.5 & 3.5 & 349.9 & 36.5 \\
CB16 & $21^{\circ} 5.373^{\prime}$ & $104^{\circ} 35.009^{\prime}$ & 9 & 9 & 8.85653 & 55.76 & 7.0 & 340.9 & 28.2 \\
Mean & \multicolumn{2}{c}{ Core level } & 51 & 50 & 49.34069 & 74.32 & 2.4 & 347.1 & 36.2 \\
Mean & \multicolumn{2}{c}{ Site level } & 4 & 4 & 3.98792 & 248.42 & 5.8 & 347.7 & 35.6 \\
\hline
\end{tabular}

\subsection{Palaeointensity results}

Michalk et al. (2008) reported a PI for the Ceboruco flow, which in their paper was erroneously assigned to the 1870 flow (their site $\mathrm{EH}$ ). The PI was determined by the MSP-DB method and provides a value of $54 \pm 6 \mu \mathrm{T}$. Here, we report new PI data, in an effort to reduce the uncertainty of this result and applying updated methods. For this PI experiment, specimens were selected from drill cores characterized by only one magnetization component, which is interpreted to be the original TRM.

A total of 30 specimens from the 1870 and Ceboruco lava flows were analysed applying the TTC PI protocol. Laboratory fields were chosen accordingly to the expected PI: $40 \mu \mathrm{T}$ for the 1870 flow and
$60 \mu \mathrm{T}$ for the Ceboruco flow, and specimens were oriented with their NRM direction parallel to the field in the furnace, with a precision better than $5^{\circ}$. Fifteen specimens passed the Thellier Tool selection criteria of class A or B (Table 3), resulting in an overall success rate of 50 per cent. Fig. 9 shows two representative examples of Arai plots, one for each lava flow and all accepted PI results are listed in Table 4 with their quality parameters. The quality parameter $q$ varies between 5.7 and 34.6; only three values of $q$ are smaller than 10. Mean PI for the 1870 flow is $45.42 \pm 6.28 \mu \mathrm{T}(n=9)$ and for the Ceboruco flow $58.96 \pm 5.82 \mu \mathrm{T}(n=6)$.

The multispecimen protocol was used only on specimens from Ceboruco lava flow, sites CB11 and CB16, with set temperatures of 


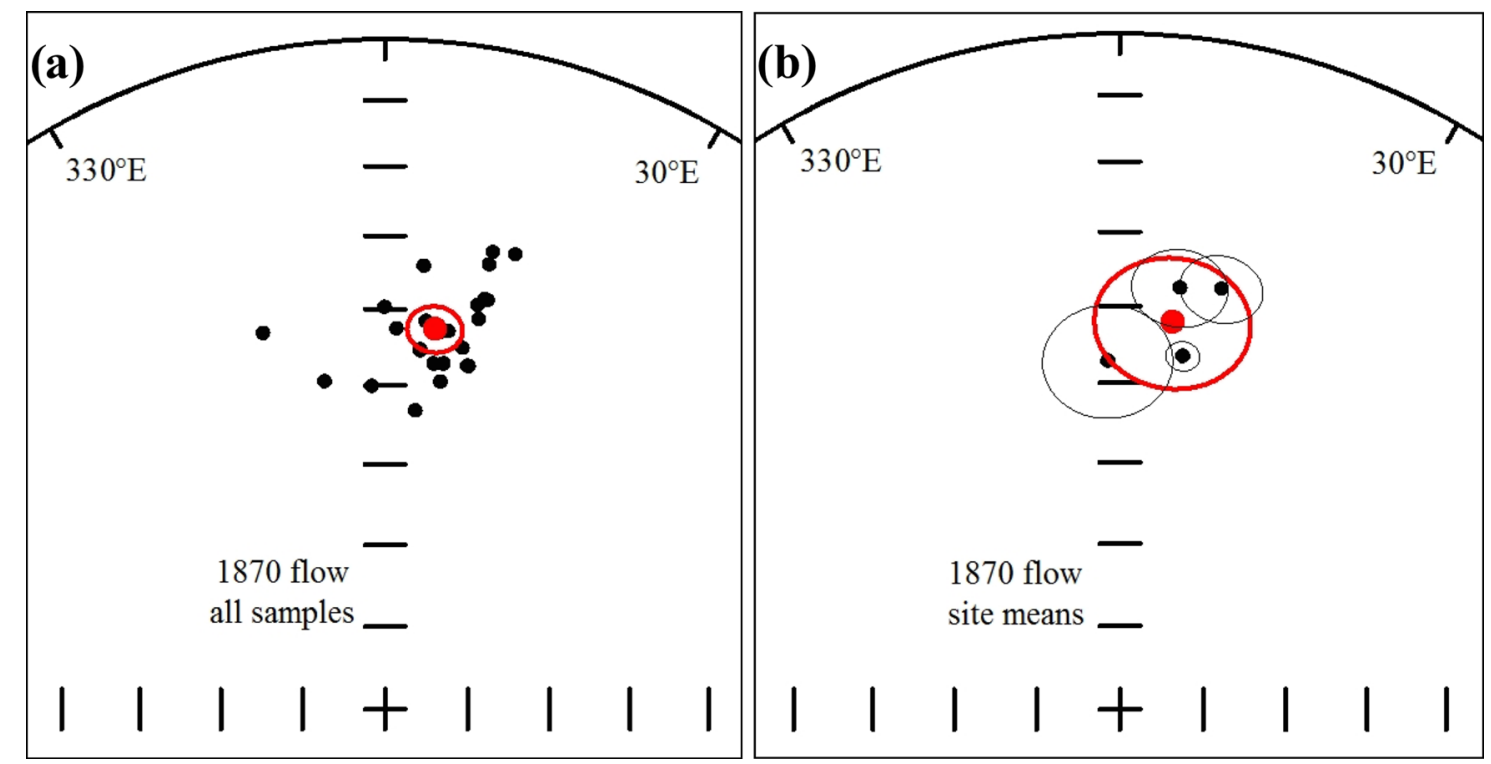

Figure 7. Characteristic remanent magnetization directions for the 1870 lava flow sampled in four sites: (a) individual directions and their overall mean; (b) site-mean directions and their overall mean. Overall mean directions are shown with larger red dots and their 95 per cent confidence angles. Equal area projection.

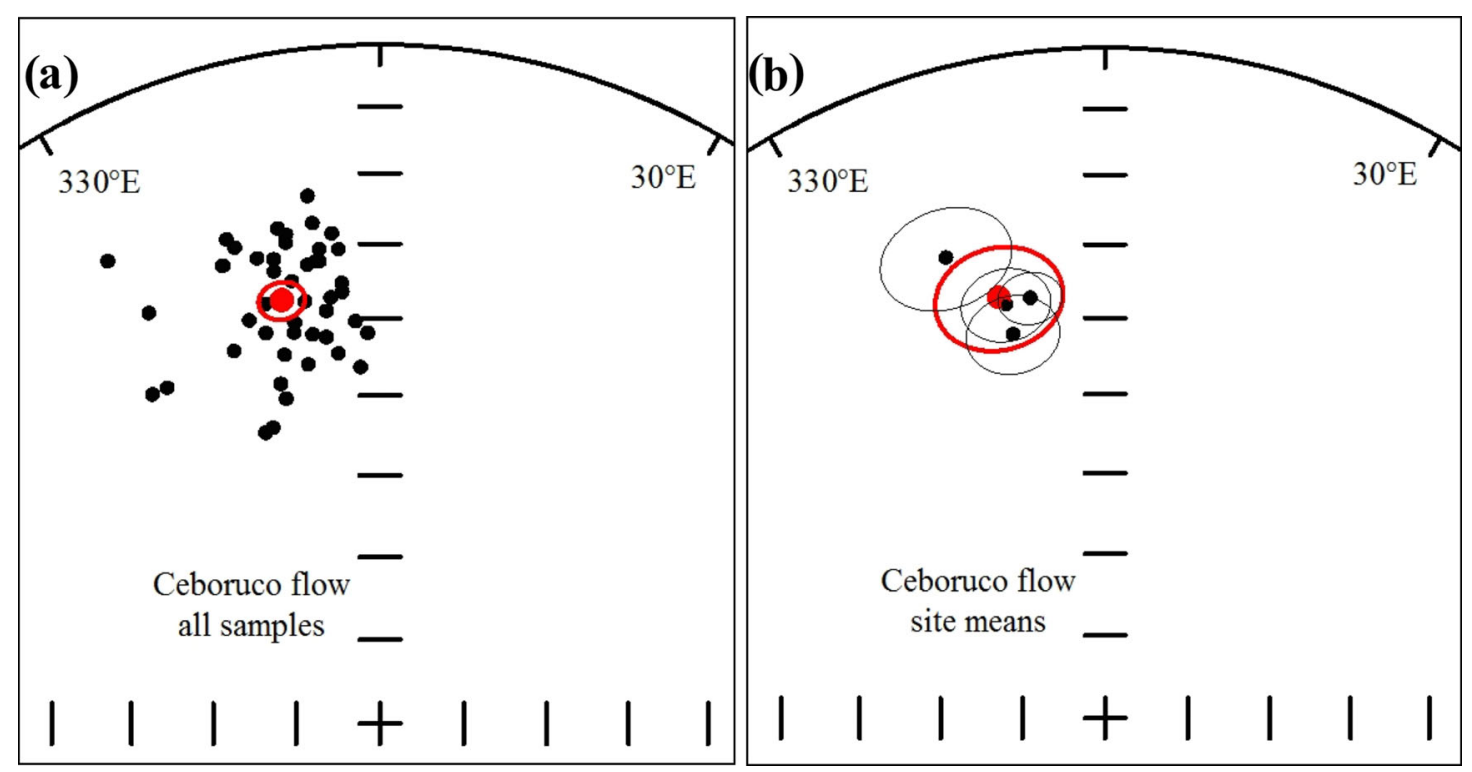

Figure 8. Characteristic remanence directions Ceboruco flow sampled in four sites: (a) individual directions and their overall mean; (b) site-mean directions and their overall mean. Overall mean directions are shown with larger red dots and their 95 per cent confidence angles. Equal area projection.

Table 3. Palaeointensity acceptance criteria: ThellierTool Class A and B (Leonhardt et al. 2004) as modified by Paterson et al. (2014). N, number of points included in the linear best fit; $f$, fraction of the NRM used for best fit; $\beta$, standard deviation divided by the slope of the best-fit line; $q$, quality factor, $\mathrm{MAD}_{\text {ang }}$, anchored maximum angular deviation; $\alpha$, angular difference between anchored and non-anchored best solution; $\delta \mathrm{CK}$, relative check error; $\delta \mathrm{pal}$, cumulative check difference; $\delta \mathrm{TR}$, tail check; $\delta t^{*}$, normalised tail of pTRM.

\begin{tabular}{lllllllllll}
\hline Class & $N$ & $f$ & $\beta$ & $q$ & $\mathrm{MAD}_{\text {ang }}$ & $\alpha$ & $\delta \mathrm{CK}$ & $\delta$ pal & $\delta \mathrm{TR}$ & $\delta t^{*}$ \\
\hline $\mathrm{A}$ & $\geq 5$ & $\geq 0.35$ & $\leq 0.1$ & $\geq 5$ & $\leq 6$ & $\leq 15$ & $\leq 7$ & $\leq 10$ & $\leq 10$ & $\leq 9$ \\
$\mathrm{~B}$ & $\geq 5$ & $\geq 0.35$ & $\leq 0.15$ & $\geq 0$ & $\leq 15$ & $\leq 15$ & $\leq 9$ & $\leq 18$ & $\leq 20$ & $\leq 99$ \\
\hline
\end{tabular}

$220^{\circ} \mathrm{C}$ and $240{ }^{\circ} \mathrm{C}$. Of the 20 specimens from CB11, 9 did not meet the required criteria and were rejected. The data are substantially scattered and the 68 per cent confidence limits for the best-fit line in Fig. 10 are large, resulting in a PI for site CB11 of $67+15 /-8.7 \mu \mathrm{T}$. For CB16, 10 specimens out of 15 passed the acceptance criteria, defining a better constrained PI of $60.3+8.5 /-6.9 \mu \mathrm{T}$. The best- fit lines for both sites cross the vertical $Q_{\mathrm{DSC}}$ axis very close to the theoretical value of -1 . Both MSP-DSC PI agree within the uncertainty limits with the TTC PI of $58.96 \pm 5.82 \mu \mathrm{T}$, but the uncertainty is too large for site $\mathrm{CB} 11(+22$ per cent/-13 per cent) to consider this to be reliable. In the case of site $\mathrm{CB} 16$, the uncertainty is similar to the TTC PI result, and the mean values are 

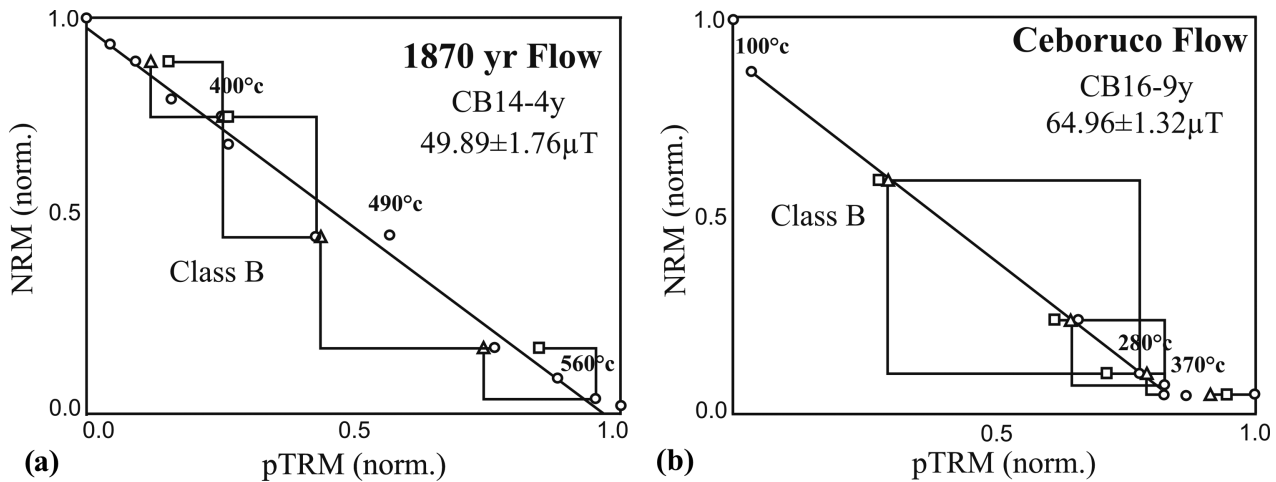

Figure 9. Examples of palaeointensity (Arai) plots for the (a) 1870 and (b) Ceboruco lava flows, obtained by the Coe version of the Thellier method. NRM and pTRM are normalized. NRM versus pTRM data are given as circles, with the black best-fit line. pTRM checks are shown by triangles and additivity checks by square symbols. The analysis was done using ThellierTool.

Table 4. Results of Thellier-Coe palaeointensity experiments for the 1870 and Ceboruco lava flows. Class, quality class according to ThellierTool (Leonhardt et al. 2004); PI \pm s.d., palaeointensity with standard deviation. Other abbreviations as in Table 3.

\begin{tabular}{|c|c|c|c|c|c|c|c|c|c|c|c|c|}
\hline Sample & $N$ & $f$ & $q$ & $\beta$ & $\mathrm{MAD}_{\text {anc }}$ & $\alpha$ & $\delta \mathrm{CK}$ & $\delta$ pal & $\delta \mathrm{TR}$ & $\delta t^{*}$ & Class & $\mathrm{PI} \pm$ s.d. $(\mu \mathrm{T})$ \\
\hline \multicolumn{13}{|c|}{1870 lava flow: CB7, 14, 25, 26} \\
\hline $14-3 z$ & 12 & 0.9 & 25.6 & 0.03 & 1.2 & 1.2 & 5.3 & 2.6 & 3.5 & 0.5 & $\mathrm{~B}$ & $58.22 \pm 1.74$ \\
\hline $14-4 y$ & 12 & 1.0 & 24.4 & 0.04 & 1.3 & 0.7 & 2.7 & 1.4 & 0.8 & 2.3 & $\mathrm{~B}$ & $49.89 \pm 1.76$ \\
\hline $14-5 Z$ & 10 & 1.0 & 7 & 0.09 & 0.9 & 0.1 & 1.9 & 3.7 & 1.2 & 0.5 & $\mathrm{~B}$ & $45.53 \pm 4.43$ \\
\hline $14-8 y$ & 10 & 0.7 & 5.7 & 0.09 & 3.5 & 3.9 & 6.7 & 9.9 & 4.6 & 2.1 & $\mathrm{~B}$ & $47.11 \pm 4.55$ \\
\hline $25-3 z$ & 12 & 1.0 & 15.9 & 0.05 & 8 & 8.7 & 9.4 & 2.7 & 2.2 & 0.3 & $\mathrm{~B}$ & $40.36 \pm 2.05$ \\
\hline $25-4 z$ & 7 & 1.0 & 34.6 & 0.02 & 9.3 & 6.1 & 0.6 & 0.3 & 1.3 & 0 & $\mathrm{~B}$ & $36.92 \pm 0.63$ \\
\hline $26-4$ & 14 & 0.9 & 18.4 & 0.04 & 2.7 & 3.5 & 10.2 & 16.6 & 1.1 & 1.7 & $\mathrm{~B}$ & $47.22 \pm 2.05$ \\
\hline $26-5 w$ & 12 & 0.9 & 13.6 & 0.06 & 2.5 & 2.4 & 2.3 & 3.1 & 1.9 & 0.5 & A & $42.66 \pm 2.57$ \\
\hline $26-6 w$ & 7 & 0.9 & 11 & 0.03 & 1.1 & 0.6 & 9.2 & 11.6 & 0.8 & 0 & $\mathrm{~B}$ & $40.88 \pm 1.45$ \\
\hline Site mean & 9 & & & & & & & & & & & $45.42 \pm 6.28$ \\
\hline \multicolumn{13}{|c|}{ Ceboruco lava flow: CB8, 9, 11, 16} \\
\hline $8-12 z$ & 8 & 0.4 & 5.8 & 0.05 & 1.4 & 1.5 & 0.5 & 0.7 & 16.3 & 4.2 & $\mathrm{~B}$ & $57.34 \pm 3.05$ \\
\hline $11-3 x$ & 10 & 0.8 & 23.3 & 0.03 & 2.2 & 2.1 & 3.3 & 5.3 & 4.8 & 1.7 & $\mathrm{~A}$ & $52.87 \pm 1.57$ \\
\hline $11-14 x$ & 6 & 0.6 & 13.5 & 0.03 & 1.9 & 2.8 & 6.1 & 1.1 & 1.3 & 3.8 & $\mathrm{~A}$ & $51.75 \pm 1.73$ \\
\hline $16-3 x$ & 6 & 0.8 & 15.8 & 0.04 & 1.9 & 2.2 & 1.7 & 2.9 & 3.1 & $\mathrm{~N}$ & $\mathrm{~A}$ & $62.45 \pm 2.61$ \\
\hline $16-6 \mathrm{w}$ & 9 & 0.9 & 18.7 & 0.04 & 2.8 & 2.3 & 6.6 & 8.3 & 6.7 & 0.8 & $\mathrm{~B}$ & $64.39 \pm 2.53$ \\
\hline $16-9 y$ & 6 & 0.9 & 29.5 & 0.02 & 1.5 & 0.9 & 1.5 & 2.3 & 0.9 & 5.3 & $\mathrm{~B}$ & $64.97 \pm 1.32$ \\
\hline Site mean & 6 & & & & & & & & & & & $58.96 \pm 5.82$ \\
\hline
\end{tabular}
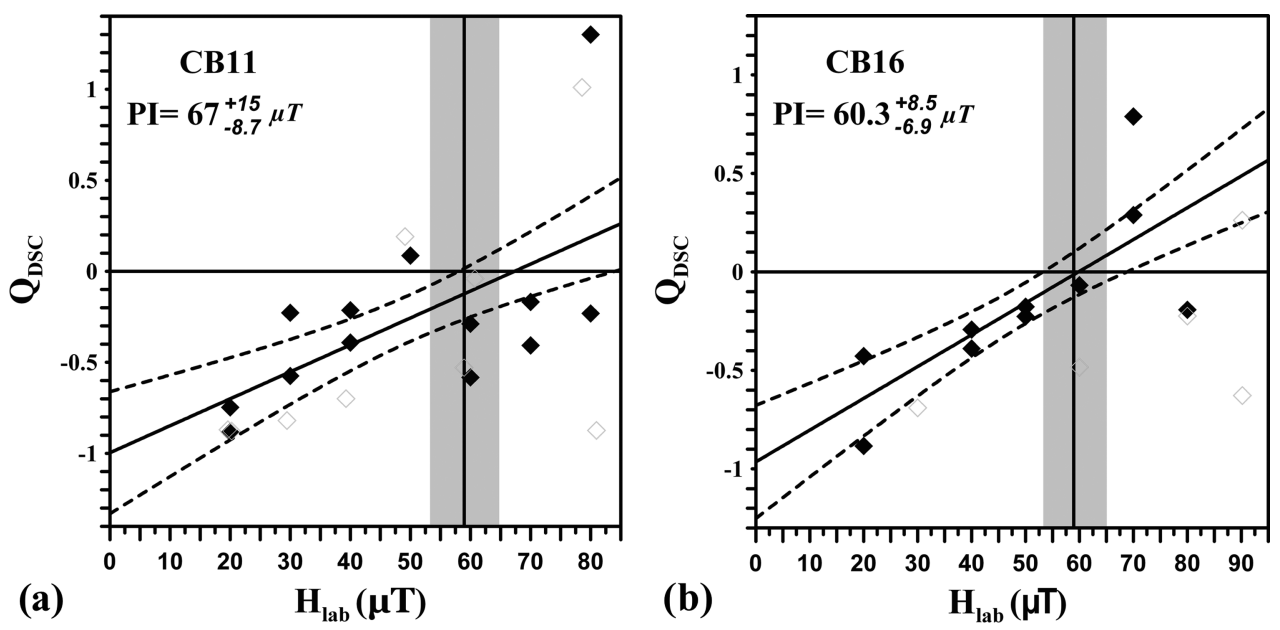

Figure 10. MSP-DSC palaeointensity results, for sites (a) CB11 and (b) CB16 of Ceboruco lava flow. Continuous black lines represent the best fit to the data shown as black diamonds, with 68 per cent confidence limits shown as dashed line. White diamonds are located outside the 95 per cent confidence limits and rejected (CB11), or were not used because of non-linearity at the $90 \mu \mathrm{T}$ field step (CB16). The vertical lines represent the site-mean Thellier-type PI results with its standard deviations (grey-shaded area). 
indistinguishable. This result is acceptable and the coincidence with the TTC result suggests that these PI data are reliable. Nevertheless, because of the difficulty to calculate a weighted mean PI from both methods, we will use only the TTC PI data for palaeomagnetic dating. Using the MSP-DSC PI would produce a very similar result.

\subsection{Palaeomagnetic dating of the 1870 and Ceboruco lava flows}

The palaeomagnetic dating was carried out with the Matlab tool archaeo_dating (Pavón-Carrasco et al. 2011) which uses PSV curves covering the last few millennia. Currently, there is not a well-constrained regional PSV curve for Mesoamerica for the last few millennia. For this reason, we used the recent global model SHA.DIF.14k (Pavón-Carrasco et al. 2014), which was developed by using only archaeomagnetic and lava flow data distributed all around the World, also including data from Central America, Mexico and the USA. For the last $400 \mathrm{yr}$, the directional model (i.e. declination and inclination) was constrained by the GUFM1 model (Jackson et al. 2000), which is based on historic field measurements. SHA.DIF.14k allows us to obtain a PSV curve with its uncertainty at any point over the Earth's surface and thus at the Ceboruco coordinates. We constrained the time interval of dating to the period 1000-1900 AD, as both lava flows were emplaced later than $1005 \mathrm{AD}$.

We already know the eruption age of the 1870 lava flow from historical accounts, and we will use the palaeodirection and intensity listed in Tables 1 and 4 to see if the archaeomagnetic dating method works. As noted above, there is an historical declination reported for the area of the Ceboruco volcano at $1875\left(9.6^{\circ}\right.$; Iglesias et al. 1877), but no information about the historical inclination and intensity is provided. For this reason, we use the full-vector (declination, inclination and intensity) palaeomagnetic information to infer a possible age for this lava flow. We use the mean directions based on all individual cores of a flow, which provides a well-constrained dating due to the low value of the $\alpha_{95}\left(3.1^{\circ}\right)$ (Fig. 11a; here only the combined PDF is shown; for details, see Supporting Information). Within the age range 1000$1900 \mathrm{AD}$, there is only one time interval in which the SHA.DIF.14k model coincides with the palaeomagnetic direction obtained from the 1870 lava flow at a 95 per cent of confidence level: 1755$1871 \mathrm{AD}$.

The same procedure was applied to date the Ceboruco lava flow using the palaeomagnetic information of Tables 2 and 3 (Fig. 11b) providing a single interval from 1000 to $1134 \mathrm{AD}$ as the most probable date of the Ceboruco flow eruption.

\section{DISCUSSION}

Bulk magnetic properties are different for the two lava flows, with the magnetic susceptibility 1.4 times larger and the NRM intensity 6.2 times large for the Ceboruco flow compared to the 1870 flow. This difference may be the consequence of the changed magma composition from andesitic to dacitic, with an accompanying reduction of the magnetic mineral concentration and maybe their grain sizes. More single-domain grain sizes would result in a higher NRM intensity than multidomain grains. As the difference in NRM is larger than in magnetic susceptibility, the Königsberger factor $Q$ is much larger for the Ceboruco flow compared to the 1870 flow. A similar trend is shown by the magnetic hysteresis data and in particular the saturation remanent magnetization $M_{\mathrm{rs}}$, which is 2.1 times larger for the Ceboruco than for the 1870 flow. This difference is much smaller for the saturation magnetization $M_{s}, 1.28$. MDF values are much higher for the Ceboruco than for the 1870 lava flow, suggesting a much larger contribution of single-domain grains to the NRM. Therefore, the observed difference in NRM intensity seems to be the result of variations in magnetic mineral concentration and/or grain sizes, together with stronger magnetic field intensity during the Ceboruco flow eruption than in 1870 , producing a stronger TRM.

ChRM directions for the 1870 flow are variable, depending on the site location. Site CB7 close to the flow tip apparently was affected by relative block movement blocks after remanence acquisition, with coherent $\mathrm{ChRM}$ directions only from one large block with extension larger than $30 \mathrm{~m}$. Sites CB13 (vent plug or dyke remnant,
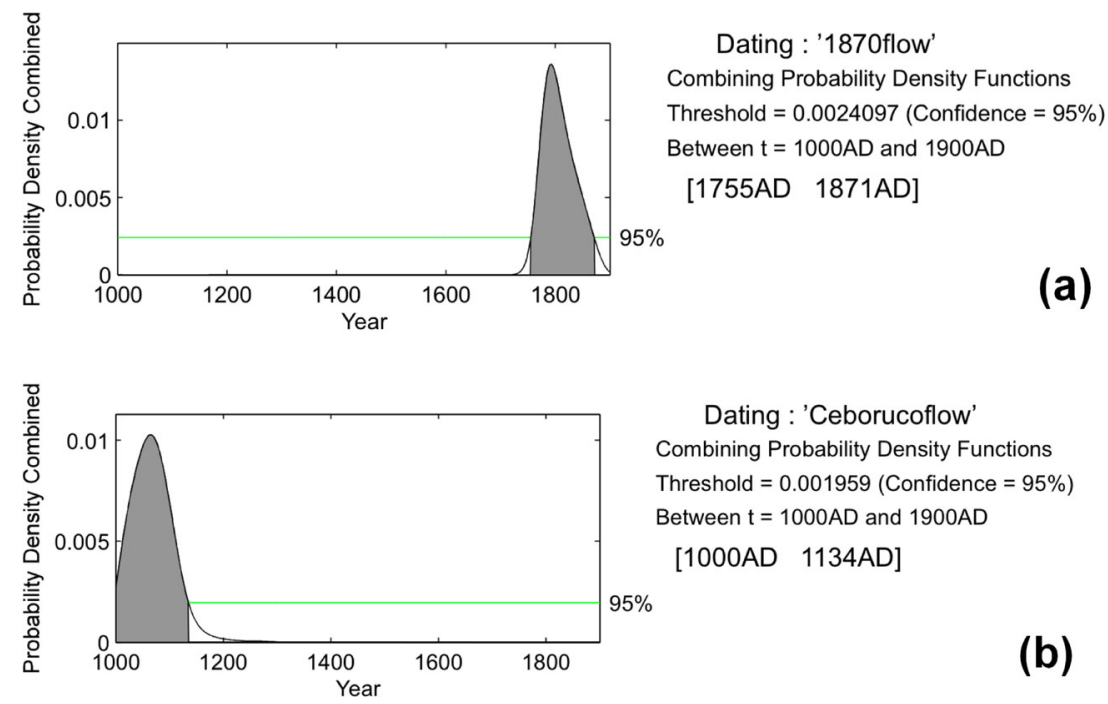

Figure 11. Palaeomagnetic dating of (a) the 1870 lava flow and (b) the Ceboruco lava flow. The combined probability density derived from the declination, inclination and palaeointensity data are shown as shaded peaks with the minimum 95 per cent confidence level by horizontal green lines. For more details, see Supporting Information. 
and nearby central dome or plug) and CB15 (levee) according to our field observations seemed not to be affected by such processes, and we expected to obtain useful ChRM directions from them. Nevertheless, directions in these sites are highly dispersed and we may only speculate that this was caused by movement of already cooled parts by later injected magma. Sites CB14, CB25 and CB26 are from the massive inner and outer wall of the 1870 vent and provide consistent ChRM directions (Fig. 8). All these observations strongly suggest sampling multiple sites to be able to recognize unreliable results and finally to recover a reliable flow-mean direction which then may be used for an accurate palaeomagnetic dating.

The outcrop situation was less complex in the case of the Ceboruco lava flow. While this flow also exhibits a very blocky surface, the interior is very well exposed by road and rail-road cuts. Contrary to our expectations this flow, situated at a much lower elevation than the 1870 vent area, was more affected by lightning strikes. Here, 12 specimens showed strong overprints, but nevertheless stable ChRM directions were obtained after demagnetization experiments. Only one specimen from the 1870 lava flow was characterized by a strong secondary magnetization component.

As listed in Tables 1 and 2, overall mean directions are available as based on individual specimens as well as based on four sitemean directions. Knowing the membership of each site to a specific flow and considering the variable number of drill cores, here we use overall flow-mean directions based on individual drill cores for palaeomagnetic dating.

In case of the 1870 lava flow, the dating results in an age range of 1755-1871 AD (Fig. 11a), which includes the historic eruption age. As SHA.DIF.14k is a global model, we consider this result as a reasonable validation of the palaeomagnetic dating method for this region. While for the period 1590-1900 AD, the directional part of the SHA.DIF.14k was constricted by the model GUFM1 (Jackson et al. 2000), the SHA.DIF.14k also includes numerous archaeomagnetic and lava flow data from the region within a radius of $1500 \mathrm{~km}$ around Ceboruco volcano for pre-historic times, and this allows its application to older rocks. Dating the Ceboruco lava flow results in an age range of 1000-1134 AD (Fig. 11b), confirming the previous assumption of being older than $1528 \mathrm{AD}$ (Sieron \& Siebe 2008). But this result also suggests that the Ceboruco lava flow was already emplaced shortly after the big plinian Jala eruption that happened around $1005 \mathrm{AD}$, and not several hundred years later as tentatively proposed by Sieron \& Siebe (2008) on the basis of the youthful appearance of this flow and its stratigraphic relation with other lava flows from Ceboruco volcano. It thus appears that all Ceboruco lava flows except the 1870 flow were emplaced shortly after $1005 \mathrm{AD}$ despite of the considerable morphologic differences and the distinct vegetation cover, and then the volcano remained inactive for at least $720 \mathrm{yr}$. This scenario looks quite different to the suggested high and sustained volcanic activity for up to $500 \mathrm{yr}$ after the $1005 \mathrm{AD}$ plinian eruption, as originally proposed by Sieron \& Siebe (2008), and will have to be taken into account for future hazard studies of Ceboruco volcano. Further on, as stratigraphically the Ceboruco lava flow may be the youngest pre-1870 flow, this much restricted age range would also have important consequences for the Ceboruco magma evolution, as it will have to allow the more or less simultaneous eruption of rocks with dacitic to basaltic andesite composition. Recently, it was reported that another Mexican volcano of similar age (El Metate, $1250 \mathrm{AD}$ ) emplaced about $9 \mathrm{~km}^{3}$ of lava within a very short time span of possibly no more than $39 \mathrm{yr}$ (Chevrel et al. 2016). Ceboruco volcano emplaced about $4 \mathrm{~km}^{3}$ of lava, but this was preceded by another $3-4 \mathrm{~km}^{3}$ of tephra during the plinian Jala eruption, all this in a similar short period of activity.

\section{CONCLUSIONS}

Two lava flows from Ceboruco volcano in western Mexico were studied in detail: the 1870 lava flow and the Ceboruco lava flow emplaced before 1528 AD but after $\sim 1005$ AD. Samples were recovered from four or more independent sites, to analyse the variability of the palaeomagnetic record, which indeed exhibits significant variations, associated to different processes. In case of the 1870 flow, which partly (or at final emplacement stages) was emplaced by inflation, post-cooling block movement produced important dispersion of observed remanence directions in two sites within the Ceboruco crater, which lead to their rejection. Four other sites provided well-clustered directions and an overall site-mean direction at $D=7.5^{\circ}, I=42.3^{\circ}, \alpha_{95}=3.1^{\circ}$ and $n=25$. The Ceboruco lava flow was studied in four well-suited sites which provide a mean direction of $D=347.1^{\circ}, I=36.2^{\circ}, \alpha_{95}=2.4^{\circ}$ and $n=51$. For both lava flows, individual site-mean directions may deviate significantly from the overall mean direction, which we consider to be the best approximation of the palaeofield during the cooling of the lava flows. Palaeointensities were obtained by the Thellier-Coe method and the multiple specimen method. Here, we use the data from the Thellier-Coe method, resulting in flow-mean palaeointensities of $45.4 \pm 6.3 \mu \mathrm{T}, N=9$ (1870 flow) and $59.0 \pm 5.8 \mu \mathrm{T}, N$ $=6$ (Ceboruco flow). Multispecimen palaeointensities are indistinguishable from this value, with a similar uncertainty in one site, but a large uncertainty in the other. The agreement of palaeointensities obtained with different methods supports that these data are correct.

The palaeomagnetic dating of the 1870 flow results in an age range of 1755-1871 AD, which includes the real emplacement age of 1870. In case of the Ceboruco lava flow, considered to be the youngest flow of the volcano apart of the 1870 flow, the dating resulted in an age range between 1000 and $1134 \mathrm{AD}$, which is close to the plinian Jala eruption of $\sim 1005 \mathrm{AD}$. This result restricts the eruption of all seven post-plinian lava flows from Ceboruco volcano to a short period of $\leq 140 \mathrm{yr}$ after this plinian event, and defines a much longer period of volcanic inactivity than suggested previously. Accordingly, Ceboruco volcano was inactive for at least $720 \mathrm{yr}$, until the 1870 eruption, with implications for future volcanic hazard analysis. The short time span available for lava flow emplacement has also to be considered in modelling the magma evolution of Ceboruco volcano, in order to explain the almost simultaneous occurrence of basaltic andesites to dacitic rocks.

\section{ACKNOWLEDGEMENTS}

The authors thank F. Speranza, P. Roperch and P. Camps for their revisions which helped to improve this manuscript, as well as the editorial handling by E. Petrovsky. Ing. J. Escalante supported studies with the MicroMag AGFM and the Curie balance, and E. Nava warranted the functionality of the laboratory computers and the network. This work was supported by UNAM project IN 112712 (HB and FJPC) and Conacyt grant no. 180032 (HB and ANM). FJPC has received funding from the European Union's Horizon 2020 research and innovation programme under the Marie SklodowskaCurie grant agreement no. 659901.

\section{REFERENCES}

Arrighi, S., Tanguy, J.-C. \& Rosi, M., 2006. Eruptions of the last 2200 years at Vulcano and Vulcanello (Aeolian Islands, Italy) dated by high-accuracy archaeomagnetism, Phys. Earth planet. Inter., 159, 225-233. 
Coe, R.S., 1967. Paleo-intensities of the Earth's magnetic field determined from Tertiary and Quaternary rocks, J. geophys. Res., 72(12), $3247-3262$.

Chevrel, M.O., Guilbaud, M.-N. \& Siebe, C., 2016. The AD 1250 effusive eruption of El Metate shield volcano (Michoacán, Mexico): magma source, crustal storage, eruptive dynamics, and lava rheology, Bull. Volcanol. 78, 32, doi:10.1007/s00445-016-1020-9.

Day, R., Fuller, M. \& Schmidt, V.A., 1977. Hysteresis properties of titanomagnetites: grain-size and compositional dependence, Phys. Earth planet. Inter., 13, 260-267.

de Ciudad Real, A., 1976. Tratado curioso y docto de las grandezas de la Nueva España, 2nd edn, Vol. 2, 484 pp., Universidad Nacional Autónoma de México (originally published 1872, Madrid).

Dekkers, M.J. \& Böhnel, H.N., 2006. Reliable absolute paleointensities independent of magnetic domain state, Earth planet. Sci. Lett., 248, 508517.

Dunlop, D.J., 2002. Theory and application of the Day plot $\left(\mathrm{M}_{\mathrm{rs}} / \mathrm{M}_{\mathrm{s}}\right.$ versus $\mathrm{H}_{\mathrm{cr}} / \mathrm{H}_{\mathrm{c}}$ ) 1. Theoretical curves and tests using titanomagnetite data, $J$. geophys. Res., 107(B3), 2056, doi:10.1029/2001JB000486.

Fabian, K. \& Leonhardt, R., 2010. Multiple-specimen absolute paleointensity determination: an optimal protocol including pTRM normalization, domain-state correction, and alteration test, Earth planet. Sci. Lett., 297(1), 84-94.

Fisher, R.A., 1953. Dispersion on a sphere, Proc. R. Soc. London, A-127, 205-305.

Frey, H.M., Lange, R.A., Hall, C.M. \& Delgado-Granados, H., 2004. Magma eruption rates constrained by ${ }^{40} \mathrm{Ar} /{ }^{39} \mathrm{Ar}$ chronology and GIS for the Ceboruco-San Pedro volcanic field, western Mexico, Bull. geol. Soc. Am., 116, 259-276.

Gallet, Y., Genevey, A. \& Le Goff, M., 2002. Three millennia of directional variations of the Earth's magnetic field in western Europe as revealed by archaeological artefacts, Phys. Earth planet. Inter., 131, $81-89$.

García, S., 1875. Viaje al ceboruco, in Informe y Colección de Artículos Relativos a Los Fenómenos Geológicos Verificados en Jalisco en el Presente Año y en Épocas Anteriores, pp. 36-184, ed. García, S., Escuela de Artes y Oficios Guadalajara.

Gardner, J.E. \& Tait, S., 2000. The caldera-forming eruption of Volcán Ceboruco, Mexico, Bull. Volcanol., 62, 20-33.

Gómez-Paccard, M., Chauvin, A., Lanos, P., McIntosh, G., Osete, M.L., Catanzariti, G., Ruiz-Martínez, V.C. \& Núñez, J.I., 2006. First archaeomagnetic secular variation curve for the Iberian Peninsula: comparison with other data from western Europe and with global geomantetic field models, Geochem. Geophys. Geosyst., 7, Q12001, doi:10.1029/2006GC001476.

Hagstrum, J.T. \& Blinman, E., 2010. Archeomagnetic dating in western North America: an updated reference curve based on paleomagnetic and archeomagnetic data sets, Geochem. Geophys. Geosyst., 11, Q06009, doi:10.1029/2009GC002979.

Hagstrum, J.T. \& Champion, D.E., 1994. Paleomagnetic correlation of Late Quaternary lava flows in the lower east rift zone of Kilauea Volcano, Hawaii, J. geophys. Res., 99, 21 679-21 690.

Iglesias, M., Bárcena, M. \& Matute, J.I., 1877. Informe sobre los temblores de Jalisco y la erupción del Volcán "Ceboruco", An. Minist. de Fom. de México, 1, 115-196.

Jackson, A., Jonkers, A.R. \& Walker, M.R., 2000. Four centuries of geomagnetic secular variation from historical records, Phil. Trans. R. Soc. A: Math. Phys. Eng. Sci., 358(1768), 957-990.

Kirschvink, J.L., 1980. The least-squares line and plane and analysis of palaeomagnetic data, Geophys. J. R. astr. Soc., 62, 699-718.

Kovacheva, M., Boyadziev, Y., Kostadinova-Avramova, M., Jordanova, N. \& Donadini, F., 2009. Updated archeomagnetic data set of the past 8 millennia from the Sofia laboratory, Bulgaria, Geochem. Geophys. Geosyst., 10(5), doi:10.1029/2008GC002347.

Krása, D., Heunemann, C., Leonhardt, R. \& Petersen, N., 2003. Experimental procedure to detect multidomain remanence during Thellier-Thellier experiments, Phys. Chem. Earth, A/B/C, 28(16), 681-687.
Lanza, R., Meloni, A. \& Tema, E., 2005. Historical measurements of the Earth's magnetic field compared with remanence directions from lava flows in Italy over the last four centuries, Phys. Earth planet. Inter, 148(1), 97-107.

Leonhardt, R., Heunemann, C. \& Krása, D., 2004. Analyzing absolute paleointensity determinations: acceptance criteria and the software ThellierTool4.0, Geochem. Geophys. Geosyst., 5(12), Q12016, doi:10.1029/2004GC000807.

McIntosh, G. \& Catanzariti, G., 2006. An introduction to archaeomagnetic dating, Geochronometria, 25, 11-18.

Michalk, D.M., Muxworthy, A.R., Böhnel, H.N., Maclennan, J. \& Nowaczyk, N., 2008. Evaluation of the multispecimen parallel differential pTRM method: a test on historical lavas from Iceland and Mexico, Geophys. J. Int., 173, 409-420.

Monster, M.W.L., de Groot, L.V. \& Dekkers, M.J., 2015. MSP-Tool: a VBAbased software tool for the analysis of multispecimen paleointensity data, Front. Earth Sci., 3, 86, doi:10.3389/feart.2015.00086.

Mota y Padilla, M.A. de la, 1973. Historia del Reino de Nueva Galicia en la América Septentrional (1742), Colección Histórica de Obras Facsimilares, Vol. 3, INAH-Universidad de Guadalajara, 626 pp.

Nelson, S.A., 1980. Geology and Petrology of Volcan Ceboruco, Nayarit, Mexico, Bull. geol. Soc. Am., 91, 2290-3243.

Paterson, G.A., Tauxe, L., Biggin, A.J., Shaar, R. \& Jonestrask, L.C., 2014. On improving the selection of Thellier-type paleointensity data, Geochem. Geophys. Geosyst., 15(4), 1180-1192.

Pavón-Carrasco, F.J., Rodríguez-González, J., Osete, M.L. \& Torta, J.M., 2011. A Matlab tool for archaeomagnetic dating, J. Archaeol. Sci., 38, 408-419.

Pavón-Carrasco, F.J., Osete, M.L., Torta, J.M. \& De Santis, A., 2014. A geomagnetic field model for the Holocene based on archaeomagnetic and lava flow data, Earth planet. Sci. Lett., 388, 98-109.

Riisager, P. \& Riisager, J., 2001. Detecting multidomain magnetic grains in Thellier palaeointensity experiments, Phys. Earth planet. Inter., 125(1), 111-117.

Roperch, P., Chauvin, A., Lara, L.E. \& Moreno, H., 2015. Secular variation of the Earth's magnetic field and application to paleomagnetic dating of historical lava flows in Chile, Phys. Earth planet. Inter., 242, 65-78.

Siebe, C., Rodriguz-Lara, V., Schaaf, P. \& Abrams, M., 2004. Radiocarbon ages of Holocene Pelado, Guespalapa, and Chichinautzin scoria cones, south of Mexico City: implications for archeology and future hazards, Bull. Volcanol., 66, 203-225.

Sieron, K., 2009. Historia eruptiva, volúmenes emitidos y composición geoquímica e isotópica (sistemas $\mathrm{Nd}, \mathrm{Sr}, \mathrm{y} \mathrm{Pb}$ ) del Volcán Ceboruco y edificios monogenéticos contiguos, Estado de Nayarit, México, $P h D$ thesis, Posgrado en Ciencias de la Tierra, UNAM, Mexico, 152 pp.

Sieron, K. \& Siebe, C., 2008. Revised stratigraphy and eruption rates of Ceboruco stratovolcano and surrounding monogenetic vents (Nayarit, Mexico) from historical documents and new radiocarbon dates, J. Volcanol. Geotherm. Res., 176, 241-264.

Speranza, F., Branca, S., Coltelli, M., D’Ajello Caracciolo, F. \& Vigliotti, L., 2006. How accurate is "paleomagnetic dating"? New evidence from historical lavas from Mount Etna, J. geophys. Res., 111(B12), doi:10.1029/2006JB004496.

Speranza, F., Pompilio, M., D’Ajello Caracciolo, F. \& Sagnotti, L., 2008. Holocene eruptive history of the Stromboli volcano: constraints from paleomagnetic dating, J. geophys. Res., 113(B9), doi:10.1029/2007JB005139.

Tanguy, J.C., Le Goff, M., Principe, C., Arrighi, S., Chillemi, V., Paiotti, A., La Delfa, S. \& Patane, G., 2003. Archeomagnetic dating of Mediterranean volcanics of the last 2100 years: validity and limits, Earth planet. Sci. Lett. 211, 111-124.

Tello, A.F., 1968. Crónica miscelánea de la Sancta Provincia de Xalisco: libro segundo, Vol. 1, pp. 1-374, Gobierno del Estado/Universidad de Guadalajara, IJAH/INAH.

Thellier, E., 1959. Sur l'intensité du champ magnétique terrestre dans le passé historique et géologique, Ann. Geophys., 15, 285-378.

Thorpe, R.S. \& Francis, P.W., 1975. Volcan Ceboruco: a major composite volcano in the Mexican Volcanic Belt, Bull. Volcanol. 54, 201-213. 


\section{SUPPORTING INFORMATION}

Additional Supporting Information may be found in the online version of this paper:

Figure S1. Overall view of the orienting device with digital inclinometer, Sun compass and magnetic compass with ocular reading. Figure S2. Sun compass scale with $0.5^{\circ}$ subdivisions and its use on the orienting device. Note that according the positioning on the platform an angle has to be added, here $90^{\circ}$. The size of the compass is about $11 \times 11 \mathrm{~cm}^{2}$. Under favourable conditions, the shadow angle may be estimated with a $1 / 4^{\circ}$ of resolution.

Figure S3. Alternatively, a thick rod with a narrow slot may be employed. This produces a wide shadow with a narrow bright line in the middle. The rod has to be turned around its long axis to optimize the width of the bright line. View of the digital inclinometer.
Figure S4. Palaeomagnetic dating of the 1870 lava flow and the Ceboruco lava flow. Horizontal blue lines are defined by the measured declination and inclination values, with 95 per cent confidence limits shown in green. Expected declination and inclination values with their 95 per cent confidence limits according to the SHA.DIF.14k global field model are shown as red curves. Below the declination, inclination and intensity curves, the probability density is shown as shaded peaks, with the minimum 95 per cent confidence level by green lines. The combined probability density derived from these data is shown at the bottom.

(http://gji.oxfordjournals.org/lookup/suppl/doi:10.1093/gji/ ggw310/-/DC1).

Please note: Oxford University Press is not responsible for the content or functionality of any supporting materials supplied by the authors. Any queries (other than missing material) should be directed to the corresponding author for the paper. 